\title{
Ureteral Jet Flow Dynamics Can Provide Information About the Mechanism of Stone Formation
}

\author{
Üreteral Jet Akım Dinamikleri Taş Oluşum Mekanizması Hakkında Bilgi Verebilir
}

\author{
(1) Serdar Çelik'1, (1) Canan Altay2, (1) Ozan Bozkurt³, (1) Görkem Uz², (1) Ömer Demir³, (1) Mustafa Seçil2 \\ ${ }^{1}$ Gaziemir Nevvar Salih İşgören State Hospital, Clinic of Urology, İzmir, Turkiye \\ 2Dokuz Eylül University Faculty of Medicine, Department of Radiology, Izmir, Turkiye \\ ${ }^{3}$ Dokuz Eylül University Faculty of Medicine, Department of Urology, İmir, Turkiye
}

\begin{abstract}
Ureteral jet dynamics, which have been shown in recent studies to indicate stone formation mechanism in adults and children, provide information about ureteral peristaltism. The dynamics were measured with Doppler ultrasonography and included ureteral jet flows and ureteral jet patterns. In this paper, we present radiographic images of a non-obstructive lower pole stone in the right kidney and a non-obstructive upper pole stone in the left kidney measuring $<1 \mathrm{~cm}$ and ureteral jet dynamics in a 26 -year-old male patient. Our opinion is that the dynamics can provide information about stone formation mechanism.
\end{abstract}

Keywords: Ureteral jet flow, Continuous jet pattern, Mechanism of stone formation, Jet dynamics, Ureteral peristaltism

Öz

Son çalışmalarda yetişkinlerde ve çocuklarda taş oluşum mekanizmasını aydınlatan üreteral jet dinamikleri üreteral peristaltizm hakkında bilgiler vermektedir. Üreteral jet akım hızlarını ve paternlerini içeren bu jet dinamikleri Doppler ultrasonografi ile ölçülmektedir. Bu yazıda, sağ böbrekte $<1 \mathrm{~cm}$ non-obstrüktif alt pol taşı ve sol böbrekte $<1 \mathrm{~cm}$ non-obstrüktif üst pol taşı olan bir hastanın görüntülemelerinin üreteral jet dinamikleri eşliğinde sunulması amaçlandı. Bizim düşüncemiz üreteral jet dinamikleri taş oluşum mekanizması hakkında bilgiler verebilmektedir.

Anahtar Kelimeler: Üreteral jet akım, Kontinu jet patern, Taş oluşum mekanizması, Jet dinamikleri, Üreteral peristaltizm

\section{Introduction}

Ureteral jet dynamics, which have been shown to indicate stone formation mechanism in adults and children in recent studies, provide information about ureteral peristaltism $(1,2)$.

\section{Case Presentation}

We prospectively evaluated a 26-year-old male patient with a non-obstructive lower pole stone in the right kidney and a nonobstructive upper pole stone in the left kidney measuring

$<1 \mathrm{~cm}$ who underwent non-contrast computed tomography due to intermittent flank pain (Figure 1). Metabolic evaluation of $24 \mathrm{~h}$-urine collection test, urinalysis and blood-creatinine level were found to be within the normal ranges. $A$ radiologist performed Doppler ultrasonography (D-US) for the assessment of ureteral jet dynamics. D-US was performed with the patient in the supine position with full bladder after hydration with water, using a 3-5 $\mathrm{MHz}$ convex probe with angle correction (Philips HDI 5000; Bothell, WA). A sample volume with an axial length of $2 \mathrm{~mm}$ was used and the wall filter was between 50 and $100 \mathrm{~Hz}$ for D-US measurements.

Parameters were average and maximum jet-flow rate (JETave and JETmax), duration of jet-flow (JETtime) and jet-flow pattern (JETpattern), the latter described by Leung et al. $(3,4)$. The images are given in Figure 1.

Written informed consent was taken from the patient before the procedure.

Correspondence: Serdar Çelik MD, Gaziemir Nevvar Salih İşören State Hospital, Clinic of Urology, İzmir, Turkiye

E-mail: serdarcelik84@hotmail.com ORCID-ID: orcid.org/0000-0003-0939-9989

Received: 17.09.2017 Accepted: 02.03.2018

Cite this article as: Çelik S, Altay C, Bozkurt O, Uz G, Demir Ö, Seçil M. Ureteral Jet Flow Dynamics Can Provide Information About the Mechanism of Stone Formation. J Urol Surg 2019;6(1):57-58.

๑Copyright 2019 by the Association of Urological Surgery / Journal of Urological Surgery published by Galenos Publishing House. 




Figure 1. a) Bilateral kidney stones; b) $<1 \mathrm{~cm}$ non-obstructive lower pole stone in right kidney and; c) $<1 \mathrm{~cm}$ non-obstructive upper pole stone in left kidney stone of the patient on non-contrast computed tomography images; d) the ureteral jet flow of right ureter in the patient; JETave $(3.6 \mathrm{~cm} /$ $\mathrm{sec})$, JETtime ( $1.6 \mathrm{sec}$ ) and continuous JETpattern; e) the ureteral jet flow of left ureter in the patient; JETave $(5.4 \mathrm{~cm} / \mathrm{s})$, JETtime $(1 \mathrm{sec})$ and continuous JETpattern

\section{Discussion}

In recent studies, the association between non-obstructive kidney stones and ureteral jet dynamics was evaluated in adult and pediatric stone formers and JETave was found to be significantly lower in affected renal units and continuous JETpattern rate was found to be higher in affected renal units when compared with healthy renal units $(1,2)$. Also, in a renal units with a JETave of $<9.5 \mathrm{~cm} / \mathrm{sec}$ for children and $<9 \mathrm{~cm} / \mathrm{sec}$ for adults were 5.6 and 19.3 times more likely to have a kidney stone, respectively. In the current patient, the JETave was found to be $<9 \mathrm{~cm} / \mathrm{sec}$ and the JETpattern was continuous for bilateral ureters. Low JETave and continuous JETpattern of bilateral renal units were similar to that in the above mentioned studies.
Therefore, ureteral jet dynamics may also be included to the evaluation of stone formers.

In conclusion, decreased peristaltism measured with D-US included $<9 \mathrm{~cm} / \mathrm{sec}$ JETave and continuous Jetpattern, which may be an explanation for stone formation mechanism in adults.

\section{Ethics}

Informed Consent: Written informed consent was taken from the patient before the procedure.

Peer-review: Externally peer-reviewed.

\section{Authorship Contributions}

Concept: S.Ç., C.A., Design: S.Ç., C.A., Data Collection or Processing: S.Ç., C.A., G.U., Analysis or Interpretation: S.Ç., O.B., Ö.D., M.S., Literature Search: S.Ç., C.A., O.B., Writing: S.Ç.

Conflict of Interest: No conflict of interest was declared by the authors.

Financial Disclosure: The authors declared that this study received no financial support.

\section{References}

1. Celik S, Altay C, Bozkurt O, Uz G, Ongun S, Demir O, Secil M, Aslan G. Association between ureteral jet dynamics and nonobstructive kidney stones: a prospective - controlled study. Urology 2014;84:1016-1020.

2. Celik S, Bozkurt O, Altay C, Celebi Celik F, Uz G, Soylu A, Kefi A, Kavukcu S, Secil $M$, Demir 0. Evaluation of Ureteral Jet Dynamics in Pediatric Kidney Stone Formers: A Cross-sectional Study. J Pediatr Urol 2017;12:381-385.

3. Leung VY, Chu WC, Yeung CK, Metreweli C. Doppler waveforms of the ureteric jet: an overview and implications for the presence of a functional sphincter at the vesicoureteric junction. Pediatr Radiol 2007;37:417-425.

4. Leung VY, Metreweli C, Yeung CK. The ureteric jet doppler waveform as an indicator of vesicoureteric sphincter function in adults and children. An observational study. Ultrasound Med Biol 2002;28:865-872. 